\author{
УдК 792.82(47)"192" \\ DOI: https://doi.org/10.31866/2616-7646.3.1.2020.203920
}

\title{
БАЛЕТ СРСР НА ШЛЯХУ ДО ХОРЕОДРАМИ В ОПТИЦІ ХУДОЖНЬОЇ КРИТИКИ
}

\author{
Підлипська Аліна Миколаївна, \\ кандидат мистецтвознавства, професор, \\ Київський національний університет культури і мистецтв, \\ Київ, Україна, \\ https://orcid.org/0000-0002-7892-337X, \\ alinaknukimaukr.net
}

Мета статті - проаналізувати критичний дискурс авангардних пошуків балетмейстерів академічних театрів 20-х рр. ХХ ст. в СРСР крізь призму формування хореодрами. Методологія. У статті проаналізовано критичні підходи до оцінки балетмейстерських пошуків, проведено їх порівняння; також застосовано хронологічний та типологічний методи. Наукова новизна. Уперше простежено підходи критиків до розгляду експериментувань на академічній балетній сцені $20-x$ рр. ХХ ст. в СРСР в аспекті формування рис хореодрами; виявлено основні причини та наслідки переходу до хореодрами. Висновки. Поліфонізм критичного дискурсу 20-х рр. ХХ ст. в СРСР проявився в різних підходах до оцінки пошуків форми нової вистави балетмейстерами, які запропонували танцсимфонію («Велич світобудови», Ф. Лопухов), сучасну революційну тему в агітаційно-плакатній формі («Червоний вихор», Ф. Лопухов; «Смерч», К. Голейзовський), розвиток внутрішньо-танцювального потенціалу балетної вистави («Пульчинела», Ф. Лопухов), створення крупних форм із збагаченням хореографічної лексики акробатичними рухами («Крижана діва», Ф. Лопухов), формотворчі пошуки з хореографічної пластики («Йосип Прекрасний», К. Голейзовський), ексцентричну інтерпретацію балетів класичної спадщини («Лускунчик», Ф. Лопухов). Однак жодне $з$ цих художніх рішень не було визнане критиками перспективним, методи створення вистав не підтримані як стратегічні напрями розвитку сучасного балетного мистецтва в СРСР. Серед провідних критиків балету не було єдності в ключовому питанні ставленні до хореографії як основного виразного засобу балетного театру. I. Соллертинський був апологетом боротьби із класичним танцем як пережитком минулого, прагнув драматизації балету; А. Піотровський виступав за синтетичне видовище (поєднання балету, опери, драми); погляди О. Гвоздєва від визначення танцю як джерела новацій дійшли до визнання провідної ролі змістовності, відмови від абстрактності. Потенційно хореодрама, в основу якої покладено літературний твір, відповідала основним вимогам соцреалізму (реалізм, народність, конкретність). В умовах домінування драматичного змісту над формою, розвитку якої сприяє музика, відбувся відхід музики в балеті на другий план.

Ключові слова: балет; критика балету; хореодрама; драмбалет; художня критика; хореографія; танець; балетний театр. 


\section{БАЛЕТ СССР НА ПУТИ К ХОРЕОДРАМЕ В ОПТИКЕ ХУДОЖЕСТВЕННОЙ КРИТИКИ}

\author{
Пидлыпская Алина Николаевна, \\ кандидат искусствоведения, профессор, \\ Киевский национальный университет \\ культуры и искусств, \\ Киев, Украина, \\ https://orcid.org/0000-0002-7892-337X, \\ alinaknukimaukr.net
}

Цель статьи - проанализировать критический дискурс авангардных поисков балетмейстеров академических театров 20-х гг. ХХ в. в СССР сквозь призму формирования хореодрамы. Методология. В статье проанализированы критические подходы к оценке балетмейстерских поисков, проведено их сравнение; также применены хронологический и типологический методы. Научная новизна. Впервые прослежены подходы критиков к рассмотрению експериментов на академической балетной сцене 20-х гг. XX в. в СССР в аспекте формирования черт хореодрамы; выявлены основные причины и последствия перехода к хореодраме. Выводы. Полифонизм критического дискурса 20-х гг. ХХ в. в СССР проявился в различных подходах к оценке поисков формы нового спектакля балетмейстерами, которые предложили танцсимфонию («Величие мироздания», Ф. Лопухов), современную революционную тему в агитационно-плакатной форме ( «Красный вихрь» Ф. Лопухов; «Смерч», К. Голейзовский), развитие внутританцевального потенциала балетного спектакля («Пульчинелла», Ф. Лопухов), создание крупных форм с обогащением хореографической лексики акробатическими движениями («Ледяная дева», Ф. Лопухов), формообразующие поиски в хореографической пластике («Иосиф Прекрасный», К. Голейзовский), эксцентричную интерпретацию балетов классического наследия («Щелкунчик», Ф. Лопухов). Однако ни одно из этих художественных решений не было признано критиками перспективным, методы создания спектаклей не поддержаны как стратегические направ-

\section{USSR BALLET ON THE WAY TO THE CHOREODRAMA IN THE OPTICS OF ART CRITICISM}

\author{
Alina Pidlypska, \\ $\mathrm{PhD}$ in Art criticism, \\ Professor, \\ Kyiv National University of Culture and Arts, \\ Kyiv, Ukraine, \\ https://orcid.org/0000-0002-7892-337X, \\ alinaknukimaukr.net
}

The purpose of the article is to analyze the critical discourse of the avant-garde searches of the choreographers of academic theatres of the 20s years of 20th century in the USSR through the prism of the formation of choreodrama. Methodology. The article analyzes critical approaches to assessing choreographer's searches, compares them; chronological and typological methods are also applied. Scientific novelty. For the first time, the approaches of critics to the examination of experiments on the academic ballet scene of the 20s years of 20th century in the USSR in the aspect of the features of choreodrama formation were traced; the main causes and consequences of the transition to choreodrama were identified. Conclusions. Polyphonism of the critical discourse of the 1920s of 20th century in the USSR manifested itself in various approaches to assessing the search for the form of a new performance by choreographers who proposed a dance symphony ("The Greatness of the Universe", F. Lopukhov), a modern revolutionary theme in a propaganda and poster form ("Red Whirlwind" F. Lopukhov; "Tornado" K. Goleizovsky), the development of the inner dance potential of the ballet performance ("Pulcinella" F. Lopukhov), the creation of large forms with the enrichment of the choreographic vocabulary by acrobatic movements ("The Ice Maiden” F. Lopukhov), the formative searches from the choreographic plasticity ("Joseph the Beautiful" K. Goleizovsky), an eccentric interpretation of classical heritage ballets ("The Nutcracker" F. Lopukhov). However, none of these artistic decisions was recognized by promising critics, 
ления развития современного балетного искусства в СССР. Среди ведущих критиков балета не было единства в ключевом вопросе - отношении к хореографии как основному выразительному средству балетного театра. И. Соллертинский был апологетом борьбы с классическим танцем как пережитком прошлого, стремился к драматизации балета; А. Пиотровский выступал за синтетическое зрелище (сочетание балета, оперы, драмы); взгляды А. Гвоздева от определения танца как источника нововведений эволюционировали к признанию ведущей роли содержательности, отказу от абстрактности. Потенциально хореодрама, в основу которой положено литературное произведение, соответствовала основным требованиям соцреализма (реализм, народность, конкретность). В условиях доминирования драматического содержания над формой, развитию которой способствует музыка, произошел отход музыки в балете на второй план.

Ключевые слова: балет; критика балета, хореодрама; драмбалета; художественная критика; хореография; танец; балетный meamp. the methods of creating performances were not supported as strategic directions for the development of modern ballet art in the USSR. Among the leading critics of ballet there was no unity in the key issue - the attitude to choreography as the main expressive means of ballet theater. I. Sollertinsky was an apologist for the struggle with classical dance as a relic of the past, sought to dramatize ballet; A. Piotrovsky advocated a synthetic spectacle (a combination of ballet, opera, drama); A. Gvozdev's views from the definition of dance as a source of innovation evolved to the recognition of the substantiveness leading role, rejection of abstractness. Potentially choreodrama, which is based on a literary work, met the basic requirements of socialist realism (realism, nationality, concreteness). In the conditions of the dramatic content dominance over the form, the development of which is facilitated by music, there was a withdrawal of music in ballet to the background.

Keywords: ballet; ballet criticism; choreography; drama ballet; art criticism; choreography; dance; ballet theatre.

Актуальність теми дослідження. 3 огляду на соціокультурні зміни, демократизацію всіх сфер життя, глобалізаційні процеси й тотальну інформатизацію сьогодні виникає потреба в перегляді усталених консервативних підходів до багатьох феноменів культурно-мистецької сфери, у тому числі й поступу балетного театру в колишньому СРСР. Одним із найскладніших періодів у балеті Радянського Союзу став етап пошуку форми й змісту вистав та паралельного формування балетного критичного дискурсу 20-х - початку 30-х pp. XX ст., що потребує спеціальної наукової уваги.

Аналіз останніх досліджень і публікацій. Попри значний дослідницький доробок проблем балетного театру СРСР 20-Х-початку 30-х рр. ХХ ст., зокрема, хореодрами (Р. Володченков (2015), О. Розанова (2016), Є. Суриць (Суриц, 1979) та ін.), окремих питань балетної критики цього періоду (Т. Букіна (Букина, 2017), А. Підлипська (2019) та ін.), балетний критичний дискурс в аспекті формування хореодрами досі не ставав предметом спеціального дослідження.

Мета статті - проаналізувати критичний дискурс авангардних пошуків балетмейстерів академічних театрів 20-х рр. ХХ ст. в СРСР крізь призму формування хореодрами.

Виклад основного матеріалу. 1920-і рр. позначені діяльністю численних танцювальних студій у СРСР, що вели пошуки нової сучасної мови та форм хоре- 
ографічного мистецтва (наприклад, «танці машин» М. Фореггера й ін.). Паралельно $з$ реконструкціями й редакціями балетів класичної спадщини та активними дискусіями щодо долі класичного танцю (докладніше в нашій статті «Критичний дискурс інтерпретації балетної класики другої половини 1920-х - першої половини 1930-х років» (Підлипська, 2019) велися пошуки нових художніх форм балетів. Серед балетмейстерів, які встигли запропонувати власні нестандартні втілення балетних вистав на академічній сцені слід назвати Ф. Лопухова («Велич світобудови», «Червоний вихор», «Пульчинела», «Льодова діва» та ін.) та К. Голейзовського («Смерч», «Йосип Прекрасний» та ін.).

Балети Ф. Лопухова стали яскравим підтвердженням різновекторних пошуків балетного театру в перше десятиліття радянської влади. У програмному безсюжетному балеті «Велич світобудови» на музику Четвертої симфонії Л. Бетховена, що відбувся лише один раз 7 березня 1923 р. у Петроградському академічному театрі опери та балету (Суриц, 1979, с. 286), балетмейстер зробив ставку на танцювальну художню образність та широкі мистецькі узагальнення. Але публіка та критика виявились не підготовленими до сприйняття такого твору. Намагання довести, що засобами «чистого» танцю можна реалізовувати глибокі змістовні теми, не знайшли підтримки. Руйнівного удару завдав виступ А. Волинського в газеті «Життя мистецтва», де Ф. Лопухов був звинувачений у відірваності від реальності (Волынский, 1923).

Танцсимфонія «Велич світобудови», на жаль, на багато років залишилась лише персональним досвідом балетмейстера стосовно симфонізації класичного танцю. Про перспективність методу Ф. Лопухова, застосованого у «Величі світобудови», свідчить подальша історія розвитку світового балетного мистецтва - найвідомішим постановником симфонічних балетів став Дж. Баланчин, який свого часу брав участь у «Величі світобудови» (Суриц, 1979, с. 287).

«Червоний вихор» В. Дешевова в постановці Ф. Лопухова на сцені Ленінградського театру опери та балету (прем’єра відбулася 29 жовтня 1924 р.) став своєрідним символом плакатного, пролеткультівського балетного театру, перевантаженого ідеологічними метафорам, зі спрощеною хореографією та лобовим конфліктом - протиставлення «позитивного» (робітники, селяни, червоноармійці, матроси) та «негативного» (спекулянти, хулігани, п'яниці) таборів. Відомий театрознавець і критик Олексій Гвоздєв, розуміючи специфіку балетного мистецтва, де поява новітніх форм на великій сцені повинна бути підготовлена чисельними апробаціями на студійному рівні, причину невдачі «Червоного вихору» вбачав у поспіху, з яким була поставлена вистава, у відсутності достатнього часу для роботи з артистами, що звикли виконувати класичний репертуар. Однією із причин невдачі О. Гвоздєв також називає ізольованість балетного театру як апологета академічності від новітніх мистецьких процесів, що відбуваються в театральному мистецтві, небажання опанувати прийоми революційного театру (Гвоздев, 1924).

Рецензент називає «Червоний вихор» авантюрою та не підтримує відмову від класичного танцю, називаючи ситуацію «ганебним капітулюванням класики перед Далькрозом», яку не може виправдати найграндіозніша «філософська програма». За думкою рецензента, «сухий геометричний малюнок груп і рухів, застосований Ф. Лопуховим для зображення “соціалізму”, знаменує собою збіднення технічних можливостей академічного балету, і з цього шляху балет необхідно 
зняти негайно, поки він ще не висушився остаточно» (Гвоздев, 1924, с. 11). Отже, О. Гвоздєв виступає за збереження та розвиток в балеті його основного виразного засобу - танцю - і висловлює сподівання, що ця невдача постановки стане стимулом для виходу балету на шлях оновлення.

У статті «Пробудження “Сплячої красуні” (1924) О. Гвоздєв окреслює власну естетичну позицію стосовно оновлення балетного театру, не пристаючи на кардинальні заклики до знищення класичного балету, а вважаючи, «що в тайниках хореографічного мистецтва приховано щось глибоко цінне i, як не дивно, глибоко сучасне. Застарів і занепав весь антураж 3 його бароковими й рококовими шатами, але основа класичного балету - професійна майстерність актора-танцівника, який володіє самодостатньою танцювальною мовою, що мислить геометрично, або, вірніше, стереометрично, формами свого тіла як єдиним матеріалом свого ремесла, - ця основа дорогоцінна й глибоко сучасна» (Гвоздев, 1987, с. 193).

Адріан Піотровський, відомий театрознавець і критик, дотримується іншої думки. У рецензії на балет «Червоний вихор» він висловлює свої погляди на подальший шлях розвитку балету: «Нині живі три види руху: 1) класичний танець, 2) танець бульварний і 3) фізкультура комуністичної молоді. Безглузді й приречені на невдачу спроби засобами класичного балету висловити що-небудь і хоч скільки-небудь центральне в життєвідчуттях сучасності. За бульварними танцями залишається вузьке коло специфічної, але по-своєму виразності. Але справді новий танець може народитися лише 3 точних і здорових рухів юнацтва. Сюди Й повинна бути звернена увага справжніх революціонерів балету» (Пиотровский, 2019, с. 209-210). Отже, в середині 20-х рр. в СРСР навіть серед професійних театрознавців панували ідеї єдино можливого шляху розвитку радянської хореографії - фізкультурно-спортивна танцювальна естетика як мистецьке втілення культу здорового тіла.

Суголосним 3 «Червоним вихором» став балет «Смерч» Б. Бера в постановці К. Голейзовського на сцені московського Великого театру 1927 року, створений в агітаційно-плакатній естетиці, що відбувся лише один раз на генеральній репетиції. Критики встигли побачити балет і доволі різко висловитись. Наприклад, відомий театрознавець та балетний критик Віктор Івінг вважав, що «Смерч» 6 «дивним змішанням ура-агітки й витонченої еротики» (Вик, 1927).

Роком раніше на балет К. Голейзовського «Легенда про Йосипа Прекрасного» обрушилася критика Бориса Асаф’єва в «Червоній газеті» 28 січня 1926 р., де відомий музикознавець та композитор називав балет «грубо-еротичною ексцентрикою», змішанням «фізкультури з “Мулен Руж”. Рецензент звинувачував балетмейстера в захопленні напівоголеними тілами, надмірності пантоміми, монотонності, натуралістичності, гімнастичній механічності (Асафьев, 1974, с. 118-119). А О. Гвоздєв назвав творчість К. Голейзовського «безпринципним захопленням драбинками і помостами» (Гвоздев, 1987, с. 190), маючи на увазі конструктивістську сценографію «Йосипа Прекрасного», створену Б. Ердманом, яку балетмейстер вдало використовував. Загалом пластично винахідливі пошуки К. Голейзовського були визнані у 20-х pp. XX ст. формалістичними, що не відповідають високим революційним ідеалам. Великий театр позбавився надзвичайно творчого, талановитого, перспективного балетмейстера. 
Вдалим, на думку О. Гвоздєва, став балет «Пульчинелла» за мотивами старовинної італійської казки «Чотири полішинеля» на музику Дж. Перголезі в обробці I. Стравинского, що був поставлений Ф. Лопуховим у ленінградському театрі опери та балету 16 травня 1926 р. в естетиці комедії дель арте. Рецензент вважав, що саме тут «знайдена формула переходу - від старого балету до нового, формула, що розвивала лінію Фокіна, але уникала його помилок» (Гвоздев, 1926).

Прихильник чистоти балетного жанру О. Гвоздєв зазначає: балетмейстер «залишається в межах чисто танцювальної вистави і шукає виразності в засобах самої хореографії, не притягаючи насильно чужі балету “переживання”. “Пульчинелла" Лопухова - це вже не мазки й не розрізнені, хоч і барвисті плями, - а продумана конструкція, надійно й міцно зроблена. Кордебалету, що підтанцьовує тут немає; всі грають, танцюючи, і всі танці - радісна, бадьора гра... У гру залучені і речі, i навіть декорації, так що разом з яскравими комічними ефектами різних інструментів оркестру створюється балетно-комедійний спектакль, життєрадісний і веселий, словом, такий, якого в нас до цих пір ще не було» (Гвоздев, 1926).

Критики визнали партію Пульчинелли однією з найскладніших у сучасному балетному репертуарі (Суриц, 1979, с. 313). Незважаючи на успіх, «Пульчинеллу» було показано лише десять разів через фінансові проблеми з відрахуваннями за кордон авторських гонорарів І. Стравінського (Суриц, 1979, с. 315). Балет став повністю танцювальним, що доводило спроможність хореографічного мистецтва створювати нові вистави власними засобами.

Ще одним балетом, що міг стати методологічною моделлю розвитку радянського балетного театру, була постановка Ф. Лопухова «Крижана діва» на музику Е. Грига (Ленінград, 1927), що за структурою нагадував академічні балети кінця XIX ст., але насичений прийомами початку XX ст. Це був балет крупної форми (три акти), де основний виразний засіб - класичний танець - поєднувався з акробатичними комбінаціями. «Крижана діва» продовжувала в загальних рисах принципи балетів XIX ст., з виразним сюжетом, характерними танцями в другому акті (як тут не згадати «Лебедине озеро», «Лускунчик» П. Чайковського - М. Петіпа, Л. Іванова з дивертисментами характерних танців).

Попри успіх у глядачів (балет йшов на ленінградській сцені майже десять років (Суриц, 1979, с. 315), критики негативно поставилися до балету, звинувачуючи Ф. Лопухова у формалізмі, симпатії до старого класичного танцю. Попри відсутність у О. Гвоздєва категоричного ставлення до класичного танцю як пережитку минулого, він вважає, що класичний танець «Крижаної діви» «оновлений акробатизмом, змінений у бік більшої динамічності, кілька наближений до сучасного художнього смаку, охоче орієнтується на малі сценічні жанри, але, по суті, він залишається тим же чисто формальним поєднанням рухів, які властиві й старому балету» (Гвоздев, 1927). На думку О. Гвоздєва, лише формальні заміни тридцяти двох фуете старого балету на шпагати Сольвейг не оновлюють балет, не додають йому дієвості, а «безпредметні танці» поєднуються сюжетною дією механічно (Гвоздев, 1927).

Серед невдалих експериментів кардинального осучаснення балетів класичної спадщини можна назвати балет «Лускунчик» Ф. Лопухова (Ленінград,1929), який був задуманий балетмейстером як синтетична вистава зі співом та словом. Загальна конструктивістська стилістика балету суперечила музиці Чайковського 
(Лопухов, 1966, с. 232-233). Балет став, за зізнанням самого Лопухова, черговою балетмейстерською невдачею, але в черговий раз засвідчив активність пошуків нових форм радянського балету.

Успішним кроком на шляху «реабілітації» класичного танцю як основного виразного засобу балетного театру став «Червоний мак» Р. Глієра на сцені Великого театру, поставлений В. Тихомировим та В. Лащилиним (Москва, 1927), - своєрідна гібридна форма традиційної балетної лексики, новітньої тематики й постановочних прийомів. Попри відповідність тогочасним ідейним настановам та успіх у глядачів (проіснував на сцені Великого театру до 1960 р.), балет зазнав нищівної критики. А. Піотровський вважав, що «Червоний мак» «від народження потрапив у мертву хватку традиційного жанру (балетного. - А. П.), принципово протилежного й ворожого бажаній і заданій ідейній установці» (Пиотровский, 1929). Дзеркальна ситуація склалася і в Харкові, де «Червоний мак» був поставлений М. Мойсеєвим в грудні 1927 р. Наприклад, рецензент, котрий підписувався «Nevermore», звинувачував балет у тісному зв’язку із формами й засобами старого балету, у присутності «чистої балетної естетики» (сцена сну, де вмістилося традиційне балетне гран па, пишність, фантастичність) (Nevermore, 1928).

На думку О. Розанової, «Червоний мак» став провісником хореодрами в радянському балетному театрі (Розанова, 2016).

Наприкінці 1920-х рр. театрознавці мали різні погляди на перспективні шляхи розвитку балетного театру, але всі сходилися в оцінці незначних досягнень попереднього десятиліття та в необхідності реформувань. А. Піотровський пропонує зруйнувати межі мистецтв та орієнтуватися на синтетичні видовищні форми, що, на його думку, відповідають революційним вимогам. Театрознавець заперечує можливість еволюціонування хореографії як самостійного виду мистецтва, вважаючи, що систему ТРОМів (Театр робітничої молоді) треба поширити та зруйнувати межі між балетом, оперою й драмою, а провідною має стати не форма, а мета та функції видовища. «Ми будемо мати видовища святкові, розраховані на виклик колективних емоцій урочистого ствердження. Ми будемо мати спектаклі агітаційні, що мають на меті підпорядкувати глядацький зал владі тієї чи тієї соціальної теми, ми будемо мати пропагандистські вистави, завдання яких викликати учасника на філософські роздуми про основні питання дійсності», проголошував А. Піотровський (Пиотровский, 1929).

Позиція I. Соллертинського полягала в категоричному неприйнятті класичного танцю як виразного засобу балетного театру: «Балет і класика нерозривно пов’язані між собою, обидва вони належать мертвому минулому» (Соллертинский, 1929).

Поняття «драматизація», до якої схиляли критики, розумілась лише у зв'язку із сюжетом, який ототожнювали із змістовністю. Рецензенти, котрі переважно були театрознавцями, власне танцювальні засоби вважали неспроможними вирішувати складні драматургічні завдання. Не було прийнято до уваги явище «хореографічної дії», що будується за законами власної танцювальної образності за допомогою основного (на той час) виразного засобу - класичного танцю. Наприклад, І. Соллертинський вважав, що класичний танець «означати щось, носити конкретний зміст... може лише за умови його театралізації. Поза театральності він буде лише абстрактним орнаментом, арабескою, примхливим візерунком, 
де гра рухомих ліній буде розглядатися як самоціль. Щоб знову стати виразним, танець повинен перетворитися в танцювальну драму, а танцівник - у хореографічного актора» (Соллертинский, 1928).

О. Гвоздєв у 1928 р. висловлюється на сторінках газети «Життя мистецтва» щодо реформи балету, вважаючи необхідним збереження крупної форми балетної вистави, паралельно проводячи експерименти з невеликими формами. Театрознавець відверто наполягає на збереженні академічних балетів минулого, але проведенні пошуків у напрямі «мелодрам» та пантоміми на сучасний сюжет. Основною вимогою, на думку театрознавця, повинна стати змістовність, а не декоративні, абстрактні та безпредметні експерименти; питання режисури, на переконання О. Гвоздьова, стає основним для балету. У цьому ми спостерігаємо зміну поглядів на роль літератури в балеті, адже в 1925 р. О. Гвоздєв вважав, що балету «доведеться відректися від літературного підходу до сюжету й базуватися на усвідомленні своєї театральної суті» (Гвоздев, 1987, с. 264). Театрознавець допускав відмову від фабули, висловлював припущення, що без неї балет «підійде швидше й успішніше до відбиття сучасності» (Гвоздев, 1987, с. 264). Саме у висловлюваннях О. Гвоздєва вже сформульовано деякі позиції, що стануть канонічними для радянського балету на найближчі двадцять років.

Від періодів творчих пошуків шляхів розвитку балетного театру (початок - середина 20-х рр.) наприкінці 20-х - на початку 30-х pp. XX ст. розпочався поступовий перехід до жорсткого моноідеологічного мистецтва, що повинно було стати зброєю масового впливу. Показовим у цьому аспекті $\epsilon$ «Диспут про шляхи радянського балету (У зв’язку з конкурсом до XV річниці Жовтневої революції)», що був проведений 19 квітня 1932 р. у Бетховенському залі Великого театру (Москва) з участю театральних критиків П. Новицького, І. Бачелиса, Г. Геронського, розвідника Р. Абіха, поета М. Асєєва, композитора М. Чемберджи, одного з ідеологів сталінізму П. Юдіна, актора-читця Е. Камінки, виконавиці вільного танцю С. Чен та заступника завідувача балетною трупою Великого театру М. Габовича (Потёмкина, 2014, с. 585). Вже сам склад учасників диспуту свідчив про занадто заполітизовані підходи в обговоренні та прийнятті рішень щодо професійного мистецтва, адже значна частина учасників не була пов'язана з балетним мистецтвом. Попри достатньо бурхливі різноаспектні обговорення ситуації в балеті, диспут не мав суспільного резонансу, адже 23 квітня 1932 р. вийшла Постанова ЦК ВКП (б) «Про перебудову літературно-художніх організацій», що стало відправним моментом впровадження соціалістичного реалізму, у тому числі і в балеті.

Чому ж балет у подальшому пішов шляхом драматичних балетів (драмбалетів, хореодрам), поставлених за відомими літературними творами? Р. Володченков вважає, що основною причиною став потужний розвиток російського драматичного театру, зокрема, масштабний вплив режисерської методики засновника Московського художнього театру К. Станіславського («система Станіславського») (Володченков, 2015, с. 243). 3 часом стало зрозумілим, що поглиблення принципів драматичного мистецтва в балеті вихолостило його як самостійний вид мистецтва зі специфічної природою художньої образності.

Апробовані драматичним театром твори Пушкіна, Шекспіра й ін. допомогли убезпечити митців балетного театру від звинувачень у політично не виважених кроках, ідеологічних прорахунках тощо. Консервативність як одна з філогенетич- 
них рис балетного театру дала йому змогу зберегти власне мистецтво й не бути зруйнованим у період огульного звинувачення класичного танцю в застарілості.

Типовими прикладами хореодрам $\epsilon$ «Полумя Парижу» Б. Асаф’єва В. Вайнонена, «Бахчисарайський фонтан» Б. Асаф'єва - Р. Захарова, «Ромео та Джульєтта» С. Прокоф’єва - Л. Лавровського, «Лауренсія» А. Крейна -В. Чабукіані й ін. Екстраполювання принципів драматичного театру в балет сприяло своєрідному тлумаченню вимог соціалістичного реалізму (власне реалізм, конкретність, народність). Правдивість образів досягалася високим рівнем акторської майстерності, що була запорукою демонстрації реальних почуттів та емоційних проявів героїв. Наявність літературного першоджерела в більшості хореодрам давала підстави вести мову про конкретність героїв, подій балетів, граничну матеріальність усього, що відбувалося на сцені. Використання загальновідомих творів сприяло реалізації вимог щодо народності (доступність мистецтва для «простих» людей). Початок 30-х pp. XX ст. у балеті СРСР пов’язаний з упровадженням формули радянського мистецтва - «національного за формою, соціалістичного за змістом», що стала емблематичною для соціалістичного реалізму. Становлення національного репертуару балетних театрів у республіках СРСР супроводжувалося активним використанням образів фольклору та національної літератури для створення хореодрам.

Своєрідним каталізатором повсюдного звернення балетного театру до літературних творів став «Конкурс на оперу, балет та симфонію», оголошений у березні 1932 р. та приурочений до 15-річчя Жовтневої революції (1917р.). Більшість вимог були відверто антибалетними (демонстрація досягнень соціалістичного сьогодення, героїка праці й ін.). Але для балетного театру рятівною видавалася примітка до програми конкурсу, де зазначалося, що лібрето можуть бути перероблені 3 найкращих творів сучасної радянської та світової літератури (Потёмкина, 2014, c. 586). Отже, було ухвалено розвиток балету по шляху інтерпретації сюжетів літературних творів. Домінування означеного наративу призвело до непаритетних взаємин між музикою та хореографією, що частково руйнувало один з основних принципів хореографічного мистецтва - органічну взаємодію музики та хореографії. Первинність музики для хореографії дає змогу експериментувати з формою, вдаватися до пошуку нових пластичних рішень. Але формотворчі експерименти не схвалювалися радянською владою, у них вбачався західний буржуазний влив, адже в Європі та Америці в 1930-х рр. потужно розвивалися системи танцю модерн. В умовах домінування соцреалістичних вимог відбувся відхід музики в балеті на другий план.

Період «строкатих» хореографічних експериментувань 20-х років XX ст. в СРСР до початку 30-х рр. зійшов нанівець, що було зумовлено не творчою неспроможністю митців розкривати сучасні теми, створювати нові хореографічні рішення, знаходити авангардні пластичні форми й ін., а посиленням тиску на мистецьку сферу, відходом від різновекторних пошуків та дотриманням єдиного «правильного», санкціонованого партійним керівництвом курсу на соціалістичний реалізм.

Наукова новизна. Уперше простежено підходи критиків до розгляду експериментувань на академічній балетній сцені 20-х рp. XX ст. в аспекті формування рис хореодрами; виявлено основні причини та наслідки переходу до хореодрами. 
Висновки. Поліфонізм критичного дискурсу 20-х рр. ХХ ст. в СРСР проявився в різних підходах до оцінки пошуків форми нової вистави балетмейстерами, що запропонували танцсимфонію («Велич світобудови», Ф. Лопухов), сучасну революційну тему в агітаційно-плакатній формі («Червоний вихор», Ф. Лопухов; «Смерч», К. Голейзовський), розвиток внутрішньо-танцювального потенціалу балетної вистави («Пульчинела», Ф. Лопухов), створення крупних форм із збагаченням хореографічної лексики акробатичними рухами («Крижана діва», Ф. Лопухов), формотворчі пошуки з хореографічної пластики («Йосип Прекрасний», К. Голейзовський), ексцентричну інтерпретацію балетів класичної спадщини («Лускунчик», Ф. Лопухов). Однак жодне з цих художніх рішень не було визнане критиками перспективним, методи створення вистав не підтримані як стратегічні напрями розвитку сучасного балетного мистецтва в СРСР.

Серед провідних критиків балету не було єдності в ключовому питанні - ставленні до хореографії як основного виразного засобу балетного театру. І. Соллертинський був апологетом боротьби із класичним танцем як пережитком минулого, він прагнув драматизації балету; А. Піотровський виступав за синтетичне видовище (поєднання балету, опери й драми); погляди О. Гвоздєва від визначення танцю як джерела новацій дійшли до визнання провідної ролі змістовності, відмови від абстрактності.

Потенційно хореодрама, в основу якої покладено літературний твір, відповідала основним вимогам соцреалізму (реалізм, народність, конкретність). В умовах домінування драматичного змісту над формою, розвитку якої сприяє музика, відбувся відхід музики в балеті на другий план.

\section{СПИСОК БІБЛІОГРАФІЧНИХ ПОСИЛАНЬ}

Асафьев, Б. (1974). О балете: Статьи, рецензии, воспоминания. Музыка.

Букина, Т. В. (2017).«Революция на пуантах» по И. И. Соллертинскому: «вульгарная» социология классического балета. Вестник Академии Русского балета им. А. Я. Вагановой, 5, 65-76.

Вик [Ивинг, В. П.]. (1927, 25 декабря). «Смерч». Правда.

Володченков, Р. Г. (2015). Творческие принципы балетмейстеров советской хореодрамы (на примере спектаклей хореографов поколения 1960-80-х годов). Известия Самарского научного центра Российской академии наук, 17(1),243-249.

Волынский, А. (1923). Танцсимфония. Жизнь искусства, 10, 3.

Гвоздев, А. (1924). «Красный вихрь». Жизнь искусства, 46, 10-11.

Гвоздев, А. (1926, 17 мая). «Пульчинелла». Красная газета.

Гвоздев, А. (1927, 28 апреля). «Ледяная дева» (Академический балет). Красная газета.

Гвоздев, А. (1987). Театральная критика. Искусство.

Лопухов, Ф. (1966). Шестьдесят лет в балете: Воспоминания и записки балетмейстера. Искусство.

Пиотровский, А.И. (1929). Мы это пересмотрим. Жизнь искусства, 39, 4 .

Пиотровский, А. И. (2019). Театральное наследие: Исследования, театральная критика, драматургия (Т. 1: Публикации А. И. Пиотровского в периодических изданиях 19191937 гг.). Балтийские сезоны. 
Підлипська, А. (2019). Критичний дискурс інтерпретації балетної класики другої половини 1920-х - першої половини 1930-х років. Українська культура: минуле, сучасне, шляхи розвитку, 30, 264-269.

Потёмкина, С. Б. (Ред.). (2014). Диспут о путях советского балета. В В.В. Иванов (Ред.), Мнемозина. Документы и факты из истории отечественного театра ХХ века (Вып. 6, с. 585-628). Индрик.

Розанова, О. И. (2016). «Драмбалет» - взгляд из XXI века. Вестник Академии Русского балета им. А. Я. Вагановой, 1, 79-87.

Соллертинский, И.И. (1928). Зановый хореографический театр. Жизнь искусства, 25, 4.

Соллертинский, И. И. (1929). Какой же балет нам в сущности нужен? Жизнь искусства, 40, 5.

Суриц, Е. (1979). Хореографическое искусство двадцатых годов: тенденции развития. Искусство.

Nevermore. (1928). Балет «Червоний Мак» в Харківській Державній Опері. Нове мистецтво, 1, 6-7.

\section{REFERENCES}

Asafev, B. (1974). O balete: Stati, retcenzii, vospominaniia [About ballet: Articles, reviews, memoirs]. Muzyka [in Russian].

Bukina, T. V. (2017). "Revoliutciia na puantakh" po I. I. Sollertinskomu: "vulgarnaia" sotciologiia klassicheskogo baleta ["Revolution on pointes" according to I. I. Sollertinsky: "vulgar" sociology of the classical ballet]. Bulletin of Vaganova Ballet Academy, 5, 65-76 [in Russian].

Gvozdev, A. (1924). "Krasnyi vikhr" ["Red Whirlwind"]. Zhizn iskusstva, 46, 10-11 [in Russian].

Gvozdev, A. (1926, May 17). "Pulchinella" ["Pulcinella"]. Krasnaia gazeta [in Russian].

Gvozdev, A. (1927, April 28). "Ledianaia deva" (Akademicheskii balet) ["Ice Maiden" (Academic Ballet)]. Krasnaia gazeta [in Russian].

Gvozdev, A. (1987). Teatralnaia kritika [Theater criticism]. Iskusstvo [in Russian].

Lopukhov, F. (1966). Shestdesiat let v balete: Vospominaniia i zapiski baletmeistera [Sixty Years in Ballet: Memoirs and Notes of the Choreographer]. Iskusstvo [in Russian].

Nevermore. (1928). Balet "Chervonyi Mak" v Kharkivskii Derzhavnii Operi [Ballet "Red Poppy" at the Kharkiv State Opera]. Nove mystetstvo, 1, 6-7 [in Ukrainian].

Pidlypska, A. (2019). Krytychnyi dyskurs interpretatsii baletnoi klasyky druhoi polovyny 1920-kh - pershoi polovyny 1930-kh rokiv [Critical discourse of interpretation of ballet classics of the second half of the 1920s - first half of the 1930s]. Ukrainian culture: past, modern and ways of development, 30, 264-269 [in Ukrainian].

Piotrovskii, A. I. (1929). My eto peresmotrim [We will review it]. Zhizn iskusstva, 39, 4 [in Russian].

Piotrovskii, A. I. (2019). Teatralnoe nasledie: Issledovaniia, teatralnaia kritika, dramaturgiia [Theater heritage: Research, theater criticism, drama] (T. 1: Publikatcii A. I. Piotrovskogo v periodicheskikh izdaniiakh 1919-1937 gg.) [(Vol. 1: Publications of A. I. Piotrovsky in periodicals 1919-1937)]. Baltiiskie sezony [in Russian].

Potemkina, S. B. (Ed.). (2014). Disput o putiakh sovetskogo baleta [Disputes about the ways of Soviet ballet]. In V. V. Ivanov (Ed.), Mnemozina. Dokumenty i fakty iz istorii otechestvennogo teatra XX veka [Mnemosyne. Documents and facts from the history of the domestic theater of the $X X$ century] (Iss. 6, pp. 585-628). Indrik [in Russian].

Rozanova, O. I. (2016). "Drambalet" - vzgliad iz XXI veka ["Drambalet" - a view from the XXI century]. Bulletin of Vaganova Ballet Academy, 1, 79-87 [in Russian].

Sollertinskii, I. I. (1928). Za novyi khoreograficheskii teatr [For the new choreographic theater]. Zhizn iskusstva, 25, 4 [in Russian]. 
Sollertinskii, I. I. (1929). Kakoi zhe balet nam v sushchnosti nuzhen? [What kind of ballet do we really need?]. Zhizn iskusstva, 40, 5 [in Russian].

Suritc, E. (1979). Khoreograficheskoe iskusstvo dvadtcatykh godov: tendentcii razvitiia [Choreographic art of the twenties: development trends]. Iskusstvo [in Russian].

Vik [Iving, V. P.]. (1927, December 25). "Smerch" ["Tornado"]. Pravda [in Russian].

Volodchenkov, R. G. (2015). Tvorcheskie printcipy baletmeisterov sovetskoi khoreodramy (na primere spektaklei khoreografov pokoleniia 1960-80-kh godov) [Creative principles of choreographers of soviet choreodrama (exemplified by 1960-80-s choreographers' performances)]. Izvestia of Samara Scientific Center of the Russian Academy of Sciences, 17(1), 243-249 [in Russian].

Volynskii, A. (1923). Tantcsimfoniia [Dance symphony]. Zhizn iskusstva, 10, 3 [in Russian]. 